\title{
Analyzing the influence of age groups of motorcycle riders on traffic violations and accidents in small city using a structural equation model
}

\author{
I Wayan Suteja ${ }^{*}$, I. A. O. Suwati Sideman ${ }^{1}$, Maulana A A ${ }^{1}$, Dewa Made Priyantha \\ Wedagama $^{2}$, and Putu Alit Suthanaya ${ }^{2}$. \\ ${ }^{1}$ Department of Civil Engineering, Universitas Mataram, 83126, Mataram, Indonesia \\ ${ }^{2}$ Department of Civil Engineering, Universitas Udayana, Denpasar Bali, Indonesia
}

\begin{abstract}
Over the last three years, there has been a tremendous increase in the amount of road accidents in Mataram City-Lombok with majority of the victims being motorcycle riders between the ages of 16-40 years. The age difference may have an impact on the rider's behavior which in turn leads to road accidents. This study aims at investigating the influence of age groups on motorcycle riders resulting to traffic violations and road accidents in Mataram City. Data was collected using questionnaire survey for which 600 respondents participated covering 6 sub-districts in Mataram City. A Structural Equation Modeling (SEM) using AMOS V.22.0 was constructed to analyze the motorcycle rider behavior. The developed model was made up of behavioral, violation and accident latent variables, with four variables of behavior, three variables of violation, and two observed variables of accident. Three age groups were used in this study with three categories consists of 15-24 years, 25-44 years, and 45-64 years old. This study found that these riders behaviors varied significantly with regards to traffic violations. The age groups of riders between 15-24 years and 45-64 years has a $65 \%$ influence on traffic violation compared to those between the ages of 25-44 years. Traffic violations with regards to road accidents was however, found to be less significant for all age group. Traffic violations committed by riders between ages of 45-64 years were found to be $14 \%$ less than those between the ages of 15-44 years. The analysis obtained from the data indicates that there are differences among the three listed age groups.
\end{abstract}

\section{Introduction}

Traffic accidents are influenced by a couple of factors, such as environmental factors, vehicle factors, road factors and human/ driver factor (ability, discipline, emotion, and driver behavior). One of the factors associated with human factors is age. The differences in the age group of drivers have been attributed to influencing motorcycle riders. Accidents

\footnotetext{
* Corresponding author: wayansuteja@unram.ac.id
} 
are as a result of traffic violations. A traffic violation can be defined as an intervening variable (mediation variable) between the driver and the road, thereby, leading to a traffic accident. Violations and traffic accidents in Mataram City is mainly made up of motorcyclists. Therefore, there is the urgent need to study, the driving behaviors motorcycle riders have on traffic accidents, using Structural Equation Modeling (SEM). SEM was used in this study because it can explain more clearly on multivariate data. The data obtained show that violations and accidents in Mataram-Lombok City mostly involve riders between 16-40 year old (70.9\%). During the last three years, the number of traffic accidents in Mataram City-Lombok has increased significantly. Based on the data obtained from the last three years, over four thousand accidents occurred with these victims from several age groups. The accident victim for the age group of 16-40 has increased since 2015 with its victims rising from 1,061 victims in 2015 to 1,115 victims in 2016, and decreasing to 820 victims in 2017. This range of ages is different from the research result obtained from research conducted in England, where young male drivers between the ages of 18-25 and older male drivers' between the ages of 35-50 were analyzed and examined of their driving ability. Both groups showed different conceptions of their own accident risk, further generating subjective ratings of the risk of accident with fatality injury rate. The number of accident victims based on age groups from 2015 to 2017 is presented in Table 1 .

Table 1. Accident victims based on age groups 2015-2017 in NTB province.

\begin{tabular}{|c|c|c|c|c|c|c|c|c|c|c|c|c|c|c|c|c|c|}
\hline \multirow{3}{*}{ No } & \multirow{3}{*}{$\begin{array}{c}\text { Resort } \\
\text { Police Unit }\end{array}$} & \multicolumn{15}{|c|}{ Age Groups (years old) } & \multirow{3}{*}{ Tota } \\
\hline & & \multicolumn{3}{|c|}{$(10-15)$} & \multicolumn{3}{|c|}{$(16-30)$} & \multicolumn{3}{|c|}{$(31-40)$} & \multicolumn{3}{|c|}{ (41-50) } & \multicolumn{3}{|c|}{ Above 50} & \\
\hline & & 2015 & 2016 & 2017 & 2015 & 2016 & 2017 & 2015 & 2016 & 2017 & 2015 & 2016 & 2017 & 2015 & 2016 & 2017 & \\
\hline 1 & $\begin{array}{l}\text { Res } \\
\text { Mataram }\end{array}$ & 15 & 33 & 21 & 94 & 124 & 105 & 50 & 55 & 36 & 25 & 36 & 22 & 15 & 34 & 34 & 699 \\
\hline 2 & Res Lobar & 10 & 11 & 3 & 63 & 81 & 35 & 39 & 22 & 6 & 25 & 16 & 9 & 10 & 6 & 5 & 341 \\
\hline 3 & Res Loteng & 32 & 14 & 12 & 84 & 88 & 74 & 53 & 24 & 32 & 23 & 30 & 15 & 11 & 11 & 15 & 518 \\
\hline 4 & Res Lotim & 27 & 32 & 6 & 240 & 269 & 185 & 104 & 82 & 80 & 54 & 58 & 50 & 16 & 48 & 3 & 1254 \\
\hline 5 & $\begin{array}{l}\text { Res SBW } \\
\text { Barat }\end{array}$ & 4 & 6 & 9 & 15 & 21 & 13 & 14 & 18 & 0 & 10 & 5 & 7 & 4 & 8 & 2 & 133 \\
\hline 6 & $\begin{array}{l}\text { Res } \\
\text { Sumbawa }\end{array}$ & 15 & 23 & 9 & 71 & 83 & 43 & 56 & 41 & 13 & 25 & 35 & 4 & 10 & 14 & 9 & 451 \\
\hline 7 & Res Dompu & 17 & 10 & 9 & 36 & 56 & 43 & 14 & 28 & 13 & 2 & 9 & 4 & 6 & 7 & 9 & 263 \\
\hline 8 & Res Bima & 7 & 13 & 6 & 38 & 43 & 45 & 24 & 16 & 13 & 13 & 11 & 7 & 4 & 11 & 6 & 257 \\
\hline 9 & $\begin{array}{l}\text { Res Kota } \\
\text { Bima }\end{array}$ & 14 & 9 & 12 & 50 & 43 & 53 & 16 & 21 & 14 & 9 & 11 & 15 & 5 & 8 & 8 & 288 \\
\hline 10 & $\begin{array}{l}\text { Polres } \\
\text { Lotara }\end{array}$ & & & & & & 11 & & & 6 & & & 4 & & & 1 & 22 \\
\hline & $\begin{array}{c}\text { Total } \\
\text { Number }\end{array}$ & 141 & 151 & 84 & 691 & 808 & 607 & 370 & 307 & 213 & 186 & 211 & 137 & 81 & 147 & 92 & 4226 \\
\hline
\end{tabular}

The increase in the number of accidents and fatalities during the last three years was what led to this research study. Research has it that several methods can be used to analyze the effects of driving behavior on traffic accidents. One of such ways is the Structural Equation Modeling (SEM) method. Structural Equation Modeling (SEM) is a multivariate analysis technique used to understand the relationship between complex variables. In this 
analysis, the researcher used the SEM method using the AMOS software. One of the sole reasons for using the AMOS software it is its user-friendliness.

The objectives of this research are as follow: 1) to investigate the influence of motorcyclist behaviors on traffic violations among several age groups in Mataram City, 2) to evaluate the impact of traffic violations on traffic accidents by comparing the differences in several age groups in Mataram City, and 3) to examine the significance influence value for each age group.

\section{Literature review}

\subsection{Definition of age}

Age can be defined as the unit of time used to measure the time of existence of an object or creature (living or dead). For example, if someone is fifteen years old, it means that age has been measured from the day he was born until the day it was calculated.

\subsection{Definition of traffic violation and traffic accident}

Traffic violations are actions that are contrary to traffic laws, either intentionally or unintentionally committed. According to the 2009 Indonesian Traffic Law No. 22 Road Traffic and Transportation Laws, traffic accidents are an unexpected and unintentional accident involving vehicles, with or without other road users, resulting in human casualties and/ or property damage. According to Suwardi [1], traffic accidents can be defined as an incident in road traffic were at least one vehicle, is damaged and to the detriment of the victim and owner of the vehicle.

\subsection{Traffic accident factors and driver behavior}

Accident factors are identical to the factors responsible for traffic, such as road users, vehicles, roads, and environmental conditions. According to Warpani (2002), the primary cause of road accidents in Indonesia is human. This is either due to the negligence or neglect of motorists or as a result of the deliberate disobedience of traffic laws on public roads. According to Lulie (2005), a driver's behavior is defined as the behavior of a vehicle owner or user in driving and caring for a vehicle how a person drive has a significant impact on whether or not there will be an accident. Dwiyogo and Prabowo [2], beams that a driver's behavior originates from the interaction of human factors with other factors such as vehicle's condition and the road.

\subsection{Structural Equation Model}

Santoso [3], defined SEM as a multivariate statistical technique which comprises of factor analysis and regression analysis (correlation), with the aim of testing the inter-variable relationships that exist within a model, either inter-indicator with its constructor the relationship between constructs.

\subsection{Initial of research model}

The multivariate statistical technique is defined as a combination of factor and regression analysis (correlation), used to test the inter-variable relationships in a model. This 
relationship is either inter-indicator with its constructor between constructs. Researchers designed and developed a model based on the theories discussed in the previous literature reviews. The relationship model between variables is depicted in Fig. 1.

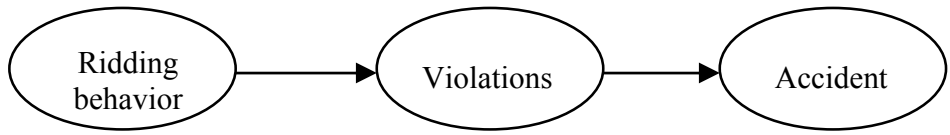

$\mathrm{H} 1$

$\mathrm{H} 2$

Fig. 1. Initial model of research.

The hypothesis used in carrying out this research study is as follows, 1) H1: Used to denote the hypothesis that driving behavior positively affects the number of traffic violations; 2) H2: Used to denote the hypothesis that traffic violations have a positive effect on traffic accidents.

\subsection{Validity test}

The instance is valid if the value of $r$ count $>r$ table and also if the questionnaire instrument can be used for data collection. Alternatively, when $r$ arithmetic $<r$ table, the instance will be declared invalid and will no longer be used in data collection. The formula used for a validity test using the product of moment technique is:

$$
r_{x y}=\frac{\sum x y}{\sqrt{\left(\sum x^{2}\right)\left(\sum y^{2}\right)}}
$$

where $R$ = relation coefficient, $X=$ the first score, in which case $\mathrm{X}$ is the scores of the item to be tested for its validity, $Y=$ the second score, in this case $\mathrm{Y}$ is the number of scores by each respondent, $\Sigma X Y=$ number of first score multiplication result with second score, $\Sigma X^{2}=$ quantity of first scores result, $\Sigma Y^{2}=$ quantity of results of the second scores. Validity testing was carried out using the SPSS program. The validity of each item can be seen by the total correlation value for each corrected question.

\subsection{Reliability test}

Reliability is described as the extent to which the measurement results obtained remain consistent, through multiple repetitions of the experiment with matching tools and circumstances.

Table 2. The level of reliability based on the Alpha values [4].

\begin{tabular}{|c|c|}
\hline Alpha & Reliability level \\
\hline $0.00-0.20$ & Less reliable \\
\hline$>0.20-0.40$ & Somewhat reliable \\
\hline$>0.40-0.60$ & Quite reliable \\
\hline$>0.60-0.80$ & Reliable \\
\hline$>0.80-1.00$ & Very reliable \\
\hline
\end{tabular}

A research instrument is said to be reliable if the reliability coefficient (r11) is $>0.6$ or greater than the $\mathrm{r}$ table [4]. The reliability tests are calculated by using the Cronbach's Alpha technique: 


$$
r_{11}=\left[\frac{k}{\sqrt{(k-1)}}\right]\left[1-\frac{\sum \sigma b^{2}}{\sigma_{1}^{2}}\right]
$$

Where $r_{11}=$ reliability instrument, $\mathrm{k}=$ the number of questions, $\Sigma \sigma b^{2}=$ number of variance point, $\sigma 1^{2}=$ all of variance. The level of reliability based on Alpha values can be seen in Table 2 .

\section{Research methods}

\subsection{Research areas, samples, variables and indicators}

A sample of 600 motorcyclists covering six sub-district in Mataram City was used to carry out this research work. Other several variables were used include 1) exogenous variable (dependent variable), such as driving behavior, 2) intermediate variable (intervening variable) i.e.the traffic violation, 3) endogenous variable (independent variable), the traffic accident. To measure the latent variables of this research, a manifest variable or an indicator is required.

Table 3. Research variables and indicators.

\begin{tabular}{|c|l|c|}
\hline \multirow{4}{*}{ Research variables } & \multicolumn{1}{|c|}{ Indicators } & Symbols \\
\hline \multirow{4}{*}{ Driving behavior } & Knowledge of driving & A1 \\
\cline { 2 - 3 } & Driving skills & A2 \\
\cline { 2 - 3 } & Emotion and physical conditions & A3 \\
\cline { 2 - 3 } Traffic violations & Discipline in driving & A4 \\
\hline & Completeness administration on riding & B1 \\
\cline { 2 - 3 } & Violations of road marking and traffic sign & B2 \\
\cline { 2 - 3 } & Precedes another vehicle from the left lane & B3 \\
\hline \multirow{3}{*}{ Traffic accident } & Perpetrator of violation & C1 \\
\cline { 2 - 3 } & Victim of the violation & C2 \\
\hline
\end{tabular}

\subsection{Sampling technique}

The population in this study consist of motorcycle riders covering six sub-districts in Mataram City. The data obtained proofs that there is an estimated total population size of 459.314 motorcycle riders. The data was obtained from the 2017 official statistic motorcycle riders statistics. According to Sugiyono [4], the sample research number can be determined using Slovin formula:

$$
n=\frac{N}{1+N \alpha^{2}}
$$

where $\alpha=$ denotes the deviation of the desired population or degree of reliability $(5 \%), N=$ population size (459.314 people), $n=$ sample size. 
From the number of population the number of samples can be calculated using Eq.

$$
\begin{aligned}
& n=\frac{N}{1+N \alpha^{2}} \quad \rightarrow \quad n=\frac{459314}{1+319900 \times 0,05^{2}} \\
& n=573,605 \approx 600 \text { sampel. }
\end{aligned}
$$

\subsection{Data collection method}

Data was collected through the use of questionnaires distributed to the motorcyclist respondents. The questionnaire used in carrying out this research study made use of a Likert scale, 1-5, to measure the attitudes of respondents towards each question. The Likert scale used in this research is as follows (Table 4).

Table 4. Likert scale with score.

\begin{tabular}{|c|c|c|}
\hline \multirow{2}{*}{ Alternative answer } & \multicolumn{2}{|c|}{ Score } \\
\cline { 2 - 3 } & Positive & Negative \\
\hline Never & 5 & 1 \\
\hline Ever & 4 & 2 \\
\hline Sometimes & 3 & 3 \\
\hline Often & 2 & 4 \\
\hline Always & 1 & 5 \\
\hline
\end{tabular}

\section{Results and discussion}

\subsection{Validity test for questionnaire instrument}

A validity test was used to measure and determine if the questionnaire instrument used was valid, or not. The instance is valid, and the instrument can be used for data collection only if $r$ count value $>r$ table value. Table 6 shows that the critical value of $r$ table is made up of a Pearson's Product Moment, with a known $r$ table value of 0.1476 for each sample number $(n)=177$ sample data and with a significance level $(\alpha)=0.05$. The result of the validity test is shown in Tabel 5.

\subsection{Structural equation modeling (SEM) analysis with the AMOS program}

The SEM process cannot be manually performed. In addition to the various limitations associated with human capabilities, the complexity of the models and statistical tools used make manual calculations inefficient. So it's essential to make use of special software for calculation such as the AMOS program. Models analyzed in this study using the AMOS program can be seen in Fig. 2.

\subsection{Normality test}

Table 6 shows that overall (multivariate) data are normally distributed with respectto the critical ratio above 1.96 for $5 \%$ significance but outside \pm 2.58 for $1 \%$ significance. 
Table 5. Validity test of the questionnaire.

\begin{tabular}{|c|c|c|c|c|c|c|c|}
\hline & $\begin{array}{c}\mathbf{r} \\
\text { analysis }\end{array}$ & $\begin{array}{c}\mathbf{r} \\
\text { statically } \\
\text { table }\end{array}$ & $\begin{array}{c}\text { Indicator } \\
\text { value } \\
\text { degree }\end{array}$ & & $\begin{array}{c}\mathbf{r} \\
\text { analysis }\end{array}$ & $\begin{array}{c}\mathbf{r} \\
\text { statically } \\
\text { table }\end{array}$ & $\begin{array}{c}\text { Indicator } \\
\text { value } \\
\text { degree }\end{array}$ \\
\hline P13 & 0.216 & 0.124 & Valid & P37 & 0.419 & 0.124 & Valid \\
\hline P10 & 0.531 & 0.124 & Valid & P4 & 0.388 & 0.124 & Valid \\
\hline P21 & 0.245 & 0.124 & Valid & P7 & 0.543 & 0.124 & Valid \\
\hline P30 & 0.534 & 0.124 & Valid & P18 & 0.572 & 0.124 & Valid \\
\hline P35 & 0.562 & 0.124 & Valid & P28 & 0.452 & 0.124 & Valid \\
\hline P9 & 0.206 & 0.124 & Valid & P6 & 0.570 & 0.124 & Valid \\
\hline P23 & 0.242 & 0.124 & Valid & P22 & 0.553 & 0.124 & Valid \\
\hline P24 & 0.587 & 0.124 & Valid & P19 & 0.528 & 0.124 & Valid \\
\hline P31 & 0.151 & 0.124 & Valid & P20 & 0.490 & 0.124 & Valid \\
\hline P32 & 0.191 & 0.124 & Valid & P25 & 0.335 & 0.124 & Valid \\
\hline P8 & 0.472 & 0.124 & Valid & P26 & 0.394 & 0.124 & Valid \\
\hline P29 & 0.633 & 0.124 & Valid & P27 & 0.416 & 0.124 & Valid \\
\hline P33 & 0.596 & 0.124 & Valid & P2 & 0.347 & 0.124 & Valid \\
\hline P1 & 0.510 & 0.124 & Valid & P3 & 0.342 & 0.124 & Valid \\
\hline P34 & 0.506 & 0.124 & Valid & P15 & 0.298 & 0.124 & Valid \\
\hline P17 & 0.434 & 0.124 & Valid & P16 & 0.381 & 0.124 & Valid \\
\hline P5 & 0.420 & 0.124 & Valid & P11 & 0.421 & 0.124 & Valid \\
\hline P14 & 0.472 & 0.124 & Valid & P12 & 0.422 & 0.124 & Valid \\
\hline P36 & 0.507 & 0.124 & Valid & & & & \\
\hline
\end{tabular}

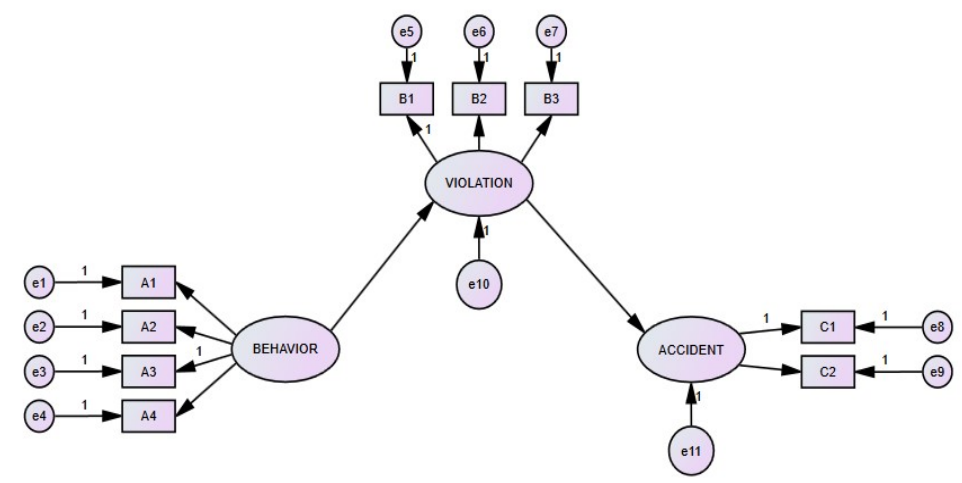

Fig. 2. The influence model of student driving behavior on traffic accidents. 
Table 6. Critical Ratio Value of each age groups.

\begin{tabular}{|c|c|c|c|}
\hline \multirow{2}{*}{$\begin{array}{c}\text { Latens of } \\
\text { variables }\end{array}$} & \multicolumn{3}{|c|}{ Critical Ratio Value } \\
\cline { 2 - 4 } & $\mathbf{3 5 - 2 4}$ & $\mathbf{2 5 - 4 4}$ & $\mathbf{4 5 - 6 4}$ \\
\cline { 2 - 4 } & -.243 & 3.286 & -1.335 \\
\hline C2 & 4.028 & .269 & -1.165 \\
\hline C1 & 2.546 & -2.017 & -.081 \\
\hline B3 & -.197 & -1.491 & -1.949 \\
\hline B2 & -1.120 & -.393 & -.464 \\
\hline B1 & -2.699 & -1.603 & -.370 \\
\hline A1 & -1.745 & 1.672 & -1.727 \\
\hline A2 & -.459 & 1.463 & 2.133 \\
\hline A3 & .105 & -2.244 & .522 \\
\hline A4 & 2.196 & 2.142 & 4.161 \\
\hline Multivariate & & & \\
\hline
\end{tabular}

Table 7. Models modification recommended of each age groups.

\begin{tabular}{|c|c|c|c|c|}
\hline $\begin{array}{c}\text { Age groups } \\
\text { (year) }\end{array}$ & $\begin{array}{c}\text { Degree of } \\
\text { Fredom }\end{array}$ & \multicolumn{2}{|c|}{$\begin{array}{c}\text { Chi-square } \leq \text { CHIINV } \\
\text { (0.05.df) }\end{array}$} & Probability $>\mathbf{0 . 0 5}$ \\
\hline $15-24$ & 17 & 16.316 & $<27.587$ & 0.502 \\
\hline $25-44$ & 16 & 8.974 & $<26.296$ & 0.914 \\
\hline $45-64$ & 18 & 13.206 & $<28.869$ & 0.779 \\
\hline \multicolumn{2}{|c|}{ Fit } & Fit \\
\hline
\end{tabular}

Table 8. Goodness-of-fit indices of models modification.

\begin{tabular}{|c|c|c|c|c|c|}
\hline \multirow{2}{*}{$\begin{array}{c}\text { Goodness- } \\
\text { of-Fit } \\
\text { Indices }\end{array}$} & \multirow{2}{*}{$\begin{array}{c}\text { Cut off } \\
\text { values }\end{array}$} & \multicolumn{3}{|c|}{ Age groups (year) } & \multirow{2}{*}{$\begin{array}{c}\text { Result fit } \\
\text { model test }\end{array}$} \\
\cline { 3 - 5 } & $\leq 2.00$ & $\mathbf{1 5 - 2 4}$ & $\mathbf{2 5 - 4 4}$ & $\mathbf{4 5 - 6 4}$ & Fit \\
\hline CMIN/DF & $\geq 0.960$ & 0.561 & 0.734 & Fit \\
\hline GFI & $\geq 0.90$ & 0.981 & 0.992 & 0.978 & Fit \\
\hline RMSEA & $\leq 0.05$ & 0.000 & 0.000 & 0.000 & Fit \\
\hline AGFI & $\geq 0.90$ & 0.950 & 0.977 & 0.944 & Fit \\
\hline TLI & $\geq 0.90$ & 1.003 & 1.030 & 1.029 & Fit \\
\hline NFI & $\geq 0.90$ & 0.965 & 0.984 & 0.964 & \\
\hline
\end{tabular}




\subsection{Modified SEM models}

In AMOS, when the SEM model is found not be a fit, it is a recommendation that the model is modified. Recommendations for model modifications will appear on the AMOS modification indices output. The result of the validity test for the revised model are shown in Tabel 7. The fit model test recommendation used to modify model is summarized Table 8. Figure 3 shows SEM models after modification for 15-24 age group.

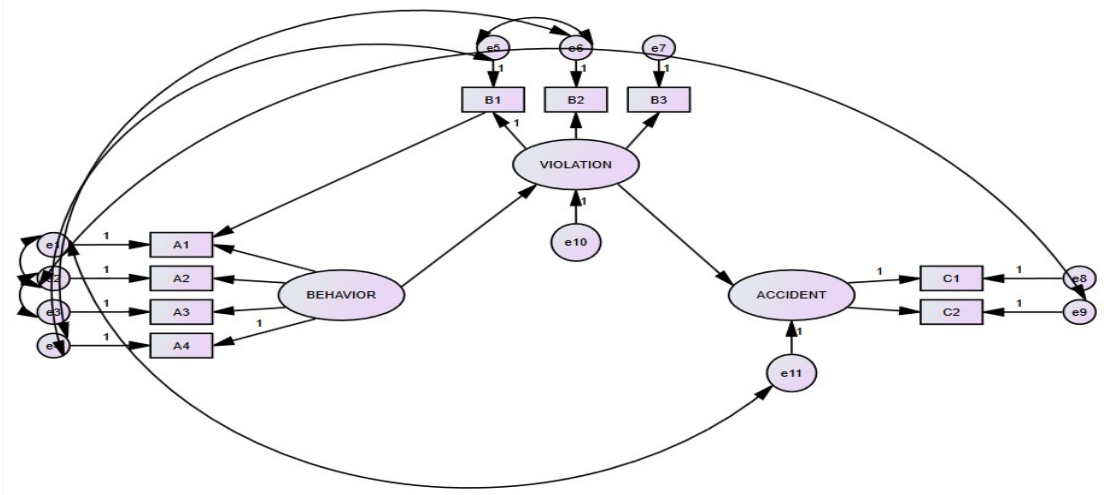

Fig. 3. SEM models after modification for 15-24 age group.

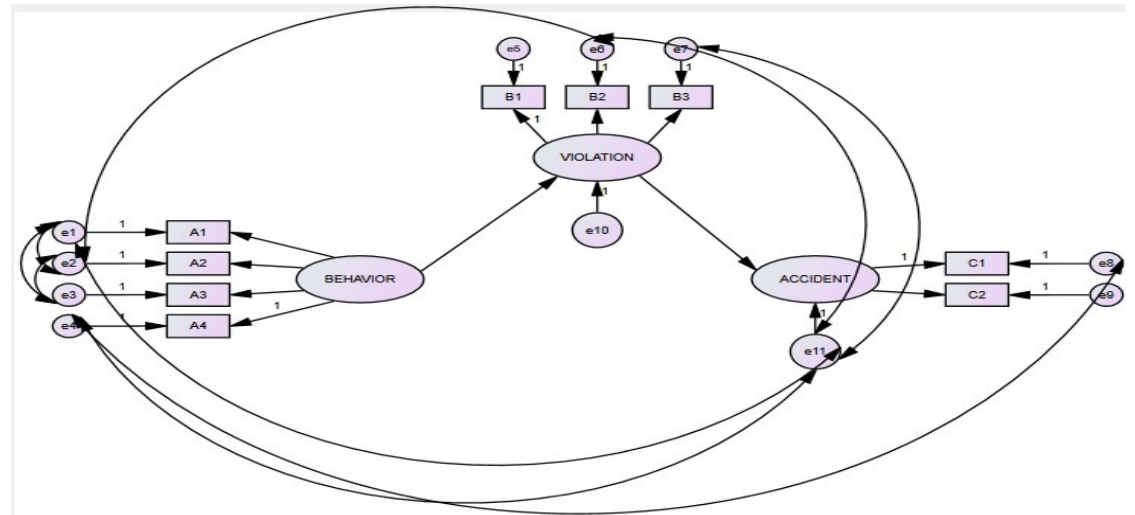

Fig. 4. SEM models after modification for 25-44 age group.

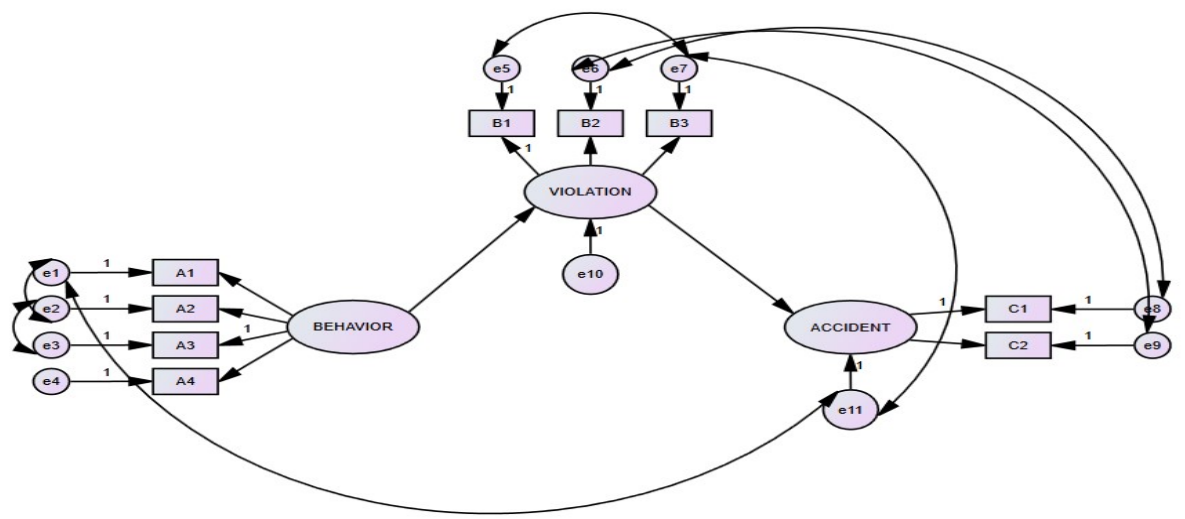

Fig. 5. SEM models after modification for 55-64 age group. 


\subsection{Analysis of indicator relationship with variables and inter-variables}

The results of the data analysis of the indicator's relationship using variable and the intervariable is presented in Table 9.

Table 9. Value of significance of loading factor.

\begin{tabular}{|l|c|c|c|c|c|c|}
\hline \multirow{2}{*}{\multicolumn{1}{c|}{ Indicators value }} & \multicolumn{2}{c|}{$\mathbf{1 5 - 2 4}$ (year) } & \multicolumn{2}{c|}{$\mathbf{2 5 - 4 4}$ (year) } & \multicolumn{2}{c|}{ 45-64 (year) } \\
\cline { 2 - 8 } & $\mathbf{C . R .}$ & $\mathbf{P}$ & $\mathbf{C . R .}$ & $\mathbf{P}$ & $\mathbf{C . R .}$ & $\mathbf{P}$ \\
\hline VIOLATIONS <--- BEHAVIOR & 2.081 & 0.037 & 3.498 & $* * *$ & 3.21 & 0.001 \\
\hline ACCIDENT <--- VIOLATIONS & 1.94 & 0.052 & 2.356 & 0.018 & 1.686 & 0.092 \\
\hline A4 <--- BEHAVIOR & & & & & & \\
\hline A3 <--- BEHAVIOR & 6.475 & $* * *$ & 5.824 & $* * *$ & 2.302 & 0.021 \\
\hline A2 <--- BEHAVIOR & 1.138 & 0.255 & 4.05 & $* * *$ & 3.308 & $* * *$ \\
\hline A1 <--- BEHAVIOR & 4.186 & $* * *$ & 4.728 & $* * *$ & & \\
\hline B1 <--- VIOLATIONS & & & & & 3.284 & 0.001 \\
\hline B2 <--- VIOLATIONS & 2.001 & 0.045 & 4.097 & $* * *$ & 3.071 & 0.002 \\
\hline B3 <--- VIOLATIONS & 2.055 & 0.04 & 4.527 & $* * *$ & & \\
\hline C1 <--- ACCIDENT & & & & & 4.894 & $* * *$ \\
\hline C2 <--- ACCIDENT & 5.486 & $* * *$ & 6.974 & $* * *$ & 7.18 & $* * *$ \\
\hline A1 <--- B1 & 4.323 & $* * *$ & & & & \\
\hline
\end{tabular}

From the above output displayed, since all $\mathrm{P}$ values are $* * *$, it can be concluded that all indicators can explain all constructs. Similarly, there is a significant relationship between constructs. In addition to the probability value $(\mathrm{P})$, a relationship is considered significant if it has a CR (Critical Ratio) value $\geq 1.96$. In the table above, all CR values have $\geq 1.96$, indicating that the relationship between the indicator and the construct, as well as the relationship between constructs is significant.

\subsection{Regression weights: (Group number 1 - Default model)}

Table 10 shows the output of standardized regression weight. Table 11 shows a close relationship between constructs to every age goups.

Table 10. Output standardized regression weight.

\begin{tabular}{|c|c|l|c|c|c|}
\hline \multicolumn{2}{|c|}{} & \multicolumn{3}{|c|}{ Estimate for each group (year) } \\
\cline { 3 - 6 } & & $\mathbf{1 5 - 2 4}$ & $\mathbf{2 5 - 4 4}$ & $\mathbf{4 5 - 6 4}$ \\
\hline A4 & $<---$ & BEHAVIOR & 0.590 & 0.739 & 0.771 \\
\hline A3 & $<---$ & BEHAVIOR & 0.695 & 0.832 & 0.692 \\
\hline
\end{tabular}




\begin{tabular}{|l|l|l|c|c|c|}
\hline \multicolumn{2}{|c|}{} & \multicolumn{3}{c|}{ Estimate for each group (year) } \\
\cline { 3 - 6 } & $\mathbf{1 5 - 2 4}$ & $\mathbf{2 5 - 4 4}$ & $\mathbf{4 5 - 6 4}$ \\
\hline A2 & $<--$ & BEHAVIOR & 0.099 & 0.441 & 0.245 \\
\hline A1 & $<---$ & BEHAVIOR & 0.362 & 0.526 & 0.329 \\
\hline B1 & $<---$ & VIOLATIONS & 0.174 & 0.347 & 0.334 \\
\hline B2 & $<---$ & VIOLATIONS & 0.626 & 0.865 & 0.713 \\
\hline B3 & $<---$ & VIOLATIONS & 0.819 & 0.568 & 0.730 \\
\hline C1 & $<---$ & ACCIDENT & 0.864 & 0.812 & 0.816 \\
\hline C2 & $<---$ & ACCIDENT & 0.705 & 0.799 & 0.830 \\
\hline A1 & $<---$ & B1 & 0.262 & - & - \\
\hline
\end{tabular}

Table 11. Squared multiple correlations value.

\begin{tabular}{|c|c|c|c|c|}
\hline \multirow{2}{*}{$\begin{array}{c}\text { Age } \\
\text { groups } \\
\text { (year) }\end{array}$} & \multicolumn{2}{|c|}{ Violations $\leftarrow$ Behavior } & \multicolumn{2}{c|}{ Accident $\leftarrow$ Violations } \\
\cline { 2 - 5 } & Influence value & Percentage & Influence value & Percentage \\
\hline $15-24$ & 0.938 & $93.8 \%$ & 0.207 & $20.7 \%$ \\
\hline $25-44$ & 0.625 & $62.5 \%$ & 0.148 & $14.8 \%$ \\
\hline $45-64$ & 0.977 & $97.7 \%$ & 0.051 & $5.1 \%$ \\
\hline
\end{tabular}

\section{Conclusions}

Based on data analysis and discussions, a few main conclusions were made. Driving behavior positively and significantly influences traffic violations. The magnitude of influence on riders of age group 15-24 years and 45-64 years is 65\% higher than riders of age group 25-44 years. This indicates that the traffic violations are more common among riders of age group 15-24 years and 25-44 years old. Traffic violations have a weak relationship to traffic accidents with factor loadings $<0.5$. The magnitude of the effect of violations committed by riders of the age group 45-64 years is $14 \%$ smaller than the number of influence riders of the age group 15-44 years. This is an indication that traffic violations do not always cause traffic accidents. There are differences in driving behavior between motorcycle riders of the age group 15-24 years, 25-44 years, and 45-64 years.

\section{References}

1. Suwardi, Simposium XII FSTPT Universitas Kristen Petra (2009)

2. P. Dwiyogo, Prabowo, Studi identifikasi daerah rawan kecelakaan (blackspot dan blacksite) pada jalan tol Jagorawi (Undergraduate Thesis, Universitas Diponegoro, Semarang, 2006)

3. S. Santoso, Statistik multivariat (PT Elex Media Komputindo, Jakarta, 2014)

4. Sugiyono, Metode penelitian kuantitatif kualitatif dan R\&D (CV Alfabeta, Bandung, 2010) 